\title{
Apportionment of Funds to Mining-Impacted Communities within Forest Reserve Environments in Ghana
}

\author{
Gordon Foli ${ }^{1}$, George Obeng ${ }^{2}$, Michael Adjaloo ${ }^{3}$, Donald Amrago ${ }^{3} \&$ Ebenezer Mensah $^{4}$ \\ ${ }^{1}$ Geological Engineering Department, Kwame Nkrumah University of Science and Technology, Kumasi, Ghana \\ ${ }^{2}$ Mechanical Engineering Department, Kwame Nkrumah University of Science and Technology, Kumasi, Ghana \\ ${ }^{3}$ Technology Consultancy Centre, Kwame Nkrumah University of Science and Technology, Kumasi, Ghana \\ ${ }^{4}$ Agriculture and Biosystems Engineering Department, Kwame Nkrumah University of Science and Technology, \\ Kumasi, Ghana \\ Correspondence: Gordon Foli, Geological Engineering Department, Kwame Nkrumah University of Science and \\ Technology, Kumasi, Ghana. Tel: 233-208-134-579. E-mail: gordon.foli01@gmail.com; gfoli.coe.knust.edu.gh
}

Received: August 9, 2018

doi:10.5539/enrr.v8n3p193
Accepted: August 23, 2018

Online Published: September 29, 2018

URL: https://doi.org/10.5539/enrr.v8n3p193

\begin{abstract}
This paper uses risk assessment of socio-economic and environmental indicators to develop criteria for apportionment (AP) of funds to communities impacted by mining activities within a Forest Reserve environment in Ghana. A t-test statistic of assessment data shows that factors such as; cost of living, health conditions, air pollution, water contamination, land degradation and distance $(\mathrm{D} \mathrm{km})$ are significant. Ratings of the factors using a 1-5 intensity scale to determine risk values (RV) for communities indicate that $R V$ of 25 requires no remediation, while (25-RV) is remediation factor. A long-term AP criterion using the ranked risk (RR) values is defined by the equation $\mathrm{AP}_{\mathrm{RR}} \%=7.45-0.233(\mathrm{RR})$ with $\mathrm{R}^{2}$ of 0.961 . Based on this criterion, communities $\mathrm{D}$ and $\mathrm{S}$ which are located at 1.5 and $16.1 \mathrm{~km}$ from the mining focus have $\mathrm{AP}_{\mathrm{RR}}$ values of $7.23 \%$ and $2.26 \%$, respectively. $\mathrm{AP}_{\mathrm{RR}} \%$ in relation to distance is defined by the equation $\mathrm{AP}_{\mathrm{RR}} \%=7.22-0.281$ (D) with $\mathrm{R}^{2}$ of 0.647 . RR-dependent distance equation $\left(\mathrm{AP}_{\mathrm{D}} \%\right)$ is used to deduce a short-term criterion defined by $\mathrm{K}^{*} \mathrm{AP} \mathrm{P}_{\mathrm{D}} \%=4.13-0.097(\mathrm{RR})$, where $\mathrm{K}$ is a constant. The expression of $\left(\mathrm{AP}_{\mathrm{RR}}-\mathrm{K}^{*} \mathrm{AP} \mathrm{P}_{\mathrm{D}}\right)$ represents the residual apportionment required after a long-term assessment. The findings in this research demonstrate well-defined patterns that can be replicated for similar future projects.
\end{abstract}

Keywords: apportionment, consequence, likelihood, environmental, remediation, risk rank

\section{Introduction}

Organised mining has been going on in Ghana since the late 1880s and contributes greatly to the local economy (Aryee, 2001). In spite of the fall in production and price of gold in recent years, the mining sector contributed some $\$ 4$ billion to Ghana's economy in 2015 (GBN, 2016). Higher revenue is expected due to the high potential for increased mineral exploration activities within the numerous mineral-bearing zones of the western half of the country (Leube et al., 1990).

The desire to increase revenue from mining triggered the inception of a Mineral Sector Reforms policy in Ghana in the mid-1980s (Akabzaa, 2000). This move resulted in increased mining activities and associated negative impacts on communities (Awudi, 2002). The impacts are exacerbated by the extension of mining concessions into Forest Reserves, however, not good enough policies are implemented to ensure effective mitigation (Akabzaa \& Darimani, 2001).

Mining impacts often result in conflicts between impacted communities and mining companies, until adequate compensations are paid to the communities (Filer et al., 2000; Ayitey et al., 2010; Kidido et al., 2015). Solving mining impact problems permanently require the assessment of the impacts on the communities to establish criteria that can be used to effect the payment of compensations. Unfortunately, however, procedures for assessing impacts are non-existent or not implemented in most developing countries due to the lack of effective legislation (Akabzaa, 2000). 
Filer et al. (2000) outlined compensation procedures using impact records collated over a total time period from 1969 to 1997 in seven mining areas in Papua New Guinea. The assessment was based on (1) available legal frameworks and land use valuation and, (2) perceptions of stakeholders about factors leading to compensation issues. Results show that compensation models developed lack standards and do not demonstrate statutory compliance. The models are also not sufficiently detailed and do not follow any specific patterns, and hence, could not be replicated for similar projects without provoking serious complications. The authors recommended that all stages of the resource development process should be involved in the evaluation process to capture more factors for the assessment.

In Ghana, impact studies of the activities of Newmont Gold Ghana Limited (NGGL) in the Ahafo and Akyem mines environments was reported in Ayitey et al. (2010) and Kidido et al. (2015). At the time, a total of 100 displaced farmers were interviewed, while group discussions were held among all other environmental stakeholders. Results of the studies show that the criteria established is substandard, as about $80 \%$ of the farmers were not pleased. The weakness of the criteria may probably be due to the general characteristics of the parameters and the small sampling size used for the assessment, considering the large coverage of the NGGL operations.

As outlined in Filer et al. (2000) compensation models to deal with social disintegration (Filer, 1990) and environmental injustice (O'Faicheallaogh, 1992) are based on private land ownership and so, may not be effective in this research. In Forest Reserve settings, land valuation is of less priority as an assessment tool for addressing community issues since the state owns the land and prohibits the users from cultivating crops that may attract huge future compensations.

The reduced role of land valuation as a parameter shifts the assessable factors determination from the domain of the environmental and government agencies to the domain of the communities and the developers. Under the circumstances, the developers are compelled to provide environmental impact data, while socio-economic impact data are generated from the communities. These sources of data may provide useful and expanded scheme that is essential for formulating good patterned criteria to address the apportionment issues.

Public perception of environmental and socioeconomic indicators are tools used to prioritize the concerns of communities in less developed settings (White \& Hunter, 2005). During the data acquisition, conflicting concerns may arise that are often difficult to resolve (Hunter, 2006). That notwithstanding, such issues are reconciled and used in shaping policy decisions (White \& Hunter 2005; Anderson et al., 2007; Harris, 2006) and environmental and economic security (Dietz et al., 2005; Xiao \& McCright, 2007).

During the inception of the Mineral Sector Reforms policy in Ghana, some mining companies were permitted to undertake exploration programmes in Production Forest Reserves, but under strict guidance. Consequently, this situation led to the entrenched deprivation of the rights of the communities to effective land use and access to good environmental and socio-economic conditions, among other benefits. To alleviate the plight of the communities, payment of compensations using an effective criterion of apportionment was deemed necessary.

Aside from the criterion for the apportionment of funds, the availability of funds to achieve the set goals is another critical issue (e.g. Banks, 2009). In Ghana, however, mining sector guidelines mandate that mining companies operating within Production Forest Reserves environments are levied with a $0.6 \%$ additional royalties (Awudi, 2002) to generate funds for the payment of compensations to impacted communities. Formulating a good criterion for the apportionment of the funds requires the use of appropriate metrics acceptable to all the stakeholders.

Kanani \& Zandi (2008) and InfoMine (2013) noted that baseline and monitoring data on project impacts may be used as indicators to establish risk levels for designing an apportionment criterion. The selection of impact indicators for the assessments are mostly without any specific standards and frameworks (Birkmann, 2007). Streamlining this, monitoring data can be characterised to establish useful relationships for use (Dietz et al., 2005; Hunter, 2006).

Asante-Duah (1996) noted that input data can be statistically manipulated to transform complex field information into likelihood and Consequence forms. The author further emphasised that such transformed data can be used for analysis or modelling, or a combination of the two to establish case-specific responses to site management problems. These steps can be cumbersome and may delay projects due to the inability of stakeholders to pay compensations at the early stage of a project since impact data are yet to be generated.

A mining project within Production Forest Reserves environment in the Western region of Ghana was started in 1994. The mining activities in the area, however, has deprived host communities of their dependency on the forest resources as a source of various forms of livelihood activities that require adequate payment of compensations. For 
about two decades, however, adequate payment of compensations was not made due to the lack of a good apportionment criterion.

The above development probably led to several violent confrontations between communities and mining companies in similarly affected areas in the past (e.g. Akabzaa \& Darimani 2001). These challenges, if not addressed would; (1) affect the successful running of the mine, (2) impede effective management of natural resources, (3) result in loss of revenue to stakeholders and finally, (4) promote moral and social degradation of the host communities.

To address the above issues, an effective criterion for apportionment in line with environmental management policy directives need to be established based on; (1) the use of reliable impact factors for the evaluations, (2) an effective reference empirical apportionment criterion developed from a historical and long-term environmental impact database, and (3) a comparative short-term apportionment criterion based on a long-term criterion.

This research combined distance (D km), environmental and socio-economic indicators with the objectives to: (1) determine significant impact factors for risk evaluation; (2) develop an empirical risk assessment and risk rank model using long-term impacts for the apportionment of funds; and (3) develop a distance-related model component for an initial apportionment at the pre-project stage. Results of the research will serve as the model criteria for the apportionment of compensations of future projects associated with environmental conservation and sustainability. It will also help by providing input data for the pre-project stage feasibility assessment and planning.

\section{Methods}

\subsection{Impact Indicators and Study Area}

Socio-economic and environmental impact indicators were assessed in the study. The socio-economic indicators include social factors such as alcoholism (AL), stealing (St), narcotic use (NA) and prostitution (Pr); economic factors such as the cost of living (CoL) and use of medicinal plants (MP), as well as health factors such as cold, cough and unclassified conditions (UC). The environmental indicators cover air pollution such as dust and noise generation (Buadee et al., 2018), water pollution (subsurface and surface) and land degradation (Akabzaa, 2000; Akabzaa et al., 2007). Finally, the shortest possible distance (D km) from the mining focus was determined.

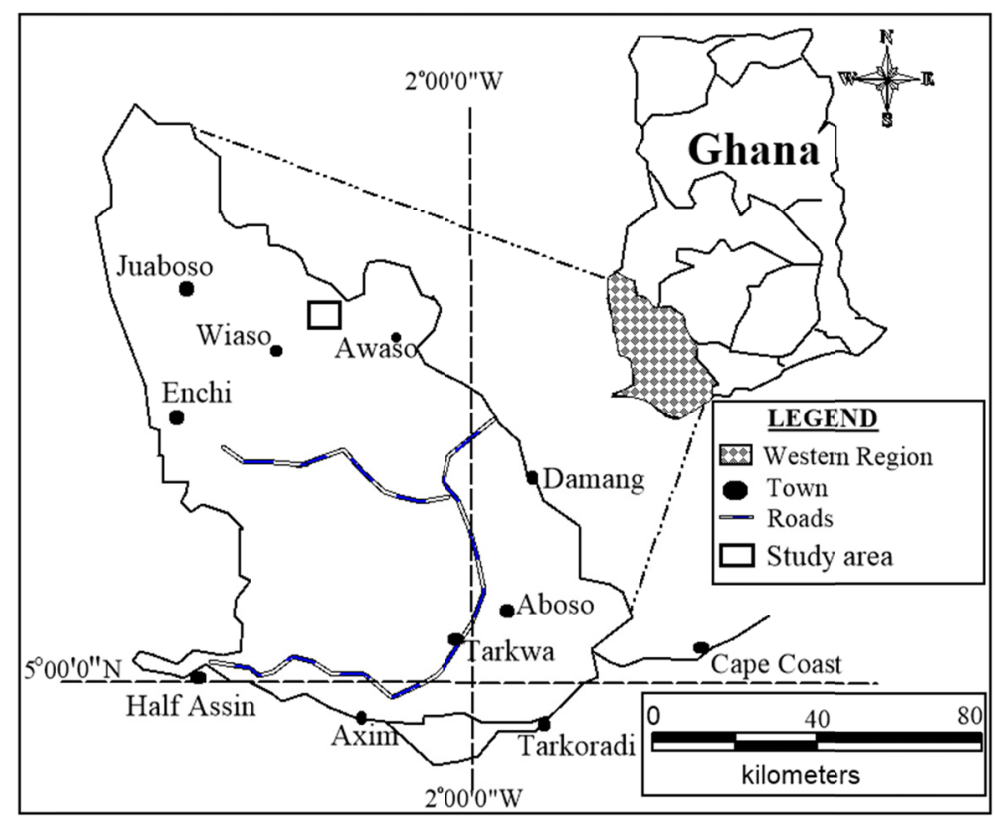

Figure 1. Sketch map showing the location of the research area

The research covered 20 selected communities. Primary data was collected through administration of questionnaires to sample public perceptions on socio-economic and environmental indicators. A total of 476 respondents made up of 20-25 from each of the communities. Saunders et al. (1997) estimated a minimum sample size of 384 people for population sizes between one 1000000 and 10000000 , hence the sample size of 476 
respondents at $5 \%$ level of significance was considered adequate for analysis for a population of about 33000 (Modern Ghana, 2018).

The ages of the respondents are from 30 years and above since the period of impact is about 20 years; this age bracket was considered good enough to provide clear evidence between pre-mining stage and mining stage impacts. The research area is located in the Western Region of Ghana (Figure 1) and characterised by a north-westerly oriented mountainous terrain that rises to about 200-450 $\mathrm{m}$ above sea level.

The climate is the tropical type with dry and wet seasons extending from November-February and May-October, respectively. Mean temperature range is $24.6-29.2^{\circ} \mathrm{C}$ (GMET, 2016). About $75 \%$ of the vegetation is the high forest zone type. Paleoproterozoic Birimian rocks characterized by abundant gold deposits occur in the area (Yao $\&$ Robb, 2000).

\subsection{Significance and Correlations of Impact Factors}

Normality tests were used to estimate $p$-values to establish data significance. A p-value $<0.05$ confidence level (CL) indicates rejection of a null hypothesis, hence the data is not significant. A p-value $>0.05 \mathrm{CL}$ indicates a failure to reject a null hypothesis, hence the data is significant. Finally, p-values very close to $0.05 \mathrm{CL}$ are considered marginal and could go either way. The correlation coefficient was used to interrelate the indicators. The sizes of the correlation coefficient are classified as $0.90-1.00$ is interpreted as very high, $0.70-0.90$ is high, $0.50-0.70$ is moderate, $0.30-0.50$ is low and $0.00-0.30$ is termed very little if any (Hinkle et al., 2003).

\subsection{Impact Rating and Risk Assessment}

Within a similar terrane in Ghana, degradation patterns of air particulate matter discharged from an ore roasting plant, and trace metals concentrations in streams were studied by Sarkodie et al. (1997), Foli et al. (2012) and Nude et al. (2016). These studies show that the contaminants reduced from discharge concentrations to the non-detection at $16 \mathrm{~km}$ away. Distances $>14 \mathrm{~km}$ is rated 5, indicating negligible likelihood while $0-3 \mathrm{~km}$ is rated 1 , and indicate disastrous likelihood. Impact intensity ranging from 80 to $100 \%$ indicate disastrous consequences, while the range from 0 to $20 \%$ indicates negligible consequences. The above rating criteria are presented in Table 1.

Table 1. Impact rating criteria

\begin{tabular}{cccc}
\hline Likelihood (L) km & Consequence (C) \% & Rating & Impact description \\
\hline$>14$ & $0-20$ & 5 & Negligible \\
$9-14$ & $21-40$ & 4 & Slightly Significant \\
$7-9$ & $41-60$ & 3 & Significant \\
$3-7$ & $61-80$ & 2 & Highly significant \\
$0-3$ & $80-100$ & 1 & Disastrous
\end{tabular}

From Table 2, the risk value (RV) was calculated as the product of likelihood (L) and consequence (C) of the impact of impact indicators on the affected communities.

\subsection{Apportionment Criterion of Compensations}

A maximum $\mathrm{RV}$ of 25 from the product of $\mathrm{L}$ and $\mathrm{C}$ constitutes a perfect condition requiring no remediation, while the least RV of 0 requires a maximum remediation. RV ranges of 16-25, 8-15.9 and 1-7.9 are classified as High, Medium and Low impacts, respectively. The difference between a variable RV and 25 attracts a remediation factor $(\mathrm{RF})$ such that a variable $(\mathrm{RF})_{i}$ is defined by:

$$
(\mathrm{RF})_{i}=(25-\mathrm{RV})_{i} .
$$

Apportionment (AP) may then be calculated using equation (1) as expressed in equation 2 :

$$
(\mathrm{AP})_{I}=\frac{R F_{i}}{\operatorname{Sum} R F} \% .
$$

\section{Results and Discussions}

\subsection{Evaluations of Impact Indicators}

The percentage responses from the selected communities to all the factors under socio-economic indicators were assessed for p-values at 95\% confidence level (CL) using the Anderson-Darling test criteria in the Minitab release 14 software are listed in Table 2. 
Table 2. Socio-economic indicators

\begin{tabular}{cccccccccc}
\hline $\begin{array}{c}\text { Impact factors } \\
\text { Community }\end{array}$ & $\mathrm{AL}$ & $\mathrm{St}$ & $\mathrm{NA}$ & $\mathrm{Pr}$ & $\mathrm{MP}$ & $\mathrm{CoL}$ & $\mathrm{UC}$ & Cold & Cough \\
\hline $\mathrm{A}$ & 29.0 & 12.0 & 12.0 & 64.7 & 17.6 & 59.0 & 82.4 & 82.0 & 41.0 \\
$\mathrm{~B}$ & 20.0 & 29.0 & 10.0 & 15.0 & 14.3 & 36.0 & 28.6 & 12.0 & 14.0 \\
$\mathrm{C}$ & 41.0 & 9.1 & 14.0 & 27.3 & 22.7 & 55.0 & 52.4 & 40.0 & 35.0 \\
$\mathrm{D}$ & 93.0 & 79.0 & 14.0 & 92.8 & 85.7 & 100 & 92.8 & 93.0 & 93.0 \\
$\mathrm{E}$ & 2.9 & 0.0 & 0.0 & 2.9 & 0.0 & 2.9 & 2.9 & 21.0 & 8.8 \\
$\mathrm{~F}$ & 12.0 & 0.0 & 6.1 & 15.2 & 6.1 & 50.0 & 3.0 & 8.6 & 42.0 \\
$\mathrm{G}$ & 8.3 & 0.0 & 0.0 & 16.7 & 33.3 & 75.0 & 4.3 & 39.0 & 21.0 \\
$\mathrm{H}$ & 33.0 & 31.0 & 7.5 & 35.0 & 22.5 & 40.0 & 57.5 & 53.0 & 50.0 \\
$\mathrm{I}$ & 69.0 & 77.0 & 69.0 & 76.9 & 83.3 & 100 & 92.3 & 92.0 & 92.0 \\
J & 0.0 & 0.0 & 0.0 & 0.0 & 4.3 & 22.0 & 95.7 & 83.0 & 74.0 \\
K & 25.0 & 29.0 & 4.2 & 4.2 & 16.7 & 38.0 & 70.8 & 29.0 & 50.0 \\
L & 17.0 & 25.0 & 21.0 & 25.0 & 65.8 & 88.0 & 90 & 92.0 & 88.0 \\
M & 6.5 & 0.0 & 3.2 & 16.1 & 0.0 & 13.0 & 57.7 & 44.0 & 41.0 \\
N & 12.0 & 5.9 & 5.9 & 29.4 & 0.0 & 18.0 & 0.0 & 5.9 & 5.9 \\
O & 0.0 & 0.0 & 0.0 & 0.0 & 0.0 & 0.0 & 23.8 & 14.0 & 14.0 \\
P & 7.4 & 11.0 & 3.7 & 48.1 & 7.4 & 56.0 & 70.4 & 70.0 & 56.0 \\
Q & 26.0 & 30.0 & 8.7 & 30.4 & 30.4 & 44.0 & 95.7 & 87.0 & 26.0 \\
R & 23.0 & 33.0 & 3.3 & 13.3 & 33.3 & 70.0 & 53.3 & 27.0 & 53.0 \\
S & 5.3 & 8.7 & 4.3 & 4.3 & 4.3 & 26.0 & 26.1 & 9.1 & 18.0 \\
T & 46.0 & 57.0 & 9.1 & 50.0 & 4.5 & 82.0 & 50.0 & 50.0 & 50.0 \\
p-value & 0.034 & $<0.005$ & $<0.005$ & 0.034 & $<0.005$ & 0.914 & 0.111 & 0.060 & 0.263 \\
\hline
\end{tabular}

In table 2, all the social factors, and the use of medicinal plants have p-values $<0.05 \mathrm{CL}$ and therefore not significant for use for interpretations. Cost of living $(\mathrm{CoL})$ and the health factors have $\mathrm{p}$-values $>0.05 \mathrm{CL}$ and hence are significant for interpretations. Similarly, data on the environmental indicators, categorised under air pollution, water pollution and land degradation, and also distance $(\mathrm{D} \mathrm{km})$ from mine focus are presented in Table 3 .

In table 3 , all the factors have p-values $>0.05 \mathrm{CL}$ and hence are significant for interpretations. All the established significant factors were the correlated as presented in Table 4.

In table 4 , economic and health factors correlate as 0.613 ; both factors correlate best with land degradation and least with water pollution. The high correlation of 0.709 of economic indicators and land degradation suggests a high dependency on land for livelihood activities. Air, water and land factors correlate highly from 0.722 to 0.834 and suggest that land degradation leads to erosion by both air and water actions. Distance correlates from -0.473 to -0.516 with the environmental factors with a decreasing intensity from a focus. The socio-economic impacts can be minimised by creating jobs, through the provision of education or alternative livelihood activities. The environmental indicators can also be addressed through environmental management planning and implementation (e.g. Foli et al., 2010). From table 1, the significant factors in tables 2 and 3 were ranked and used to calculate the consequence and likelihood of impact as presented in tables 5 .

Table 3. Environmental indicators

\begin{tabular}{ccccccc}
\hline $\begin{array}{c}\text { Impact factors } \\
\text { Community }\end{array}$ & \multirow{2}{*}{ Dkm } & Noise & Dust & Subsurface & Surface & Land \\
\hline A & 7.5 & 70.6 & 47.1 & 52.9 & 82.4 & 64.7 \\
B & 6.6 & 100.0 & 85.7 & 100 & 92.9 & 71.4 \\
C & 6.2 & 22.7 & 40.9 & 40.9 & 31.8 & 27.3 \\
D & 1.5 & 100.0 & 100 & 42.9 & 92.9 & 100 \\
E & 3.1 & 73.5 & 36.4 & 58.8 & 73.5 & 23.5 \\
F & 6.1 & 27.3 & 51.5 & 39.4 & 90.9 & 33.3 \\
G & 10.3 & 50.0 & 25.0 & 41.7 & 33.3 & 58.3 \\
H & 8.7 & 52.5 & 85.0 & 60.0 & 20.0 & 50.0 \\
I & 2.0 & 100.0 & 92.3 & 84.6 & 53.8 & 84.6 \\
J & 11.1 & 0.0 & 0.0 & 0.0 & 0.0 & 0.0 \\
K & 8.2 & 8.3 & 37.5 & 54.2 & 58.3 & 37.5 \\
L & 3.6 & 75.0 & 87.5 & 83.3 & 58.3 & 54.2 \\
M & 8.0 & 3.2 & 61.3 & 51.6 & 74.2 & 41.9 \\
N & 8.5 & 5.9 & 35.3 & 23.5 & 5.9 & 11.8 \\
O & 4.8 & 47.6 & 9.5 & 23.8 & 23.8 & 23.8 \\
P & 13.5 & 7.4 & 63.0 & 37.0 & 7.4 & 29.6 \\
Q & 14.7 & 13.0 & 30.4 & 21.7 & 30.4 & 18.3 \\
R & 11.3 & 80.0 & 76.7 & 56.7 & 40 & 36.7 \\
S & 16.1 & 60.9 & 52.2 & 34.8 & 47.8 & 30.4 \\
T & 6.8 & 72.7 & 59.1 & 63.6 & 36.4 & 54.5 \\
p-value & 0.846 & 0.093 & 0.752 & 0.573 & 0.543 & 0.617 \\
\hline
\end{tabular}


Table 4. Correlation of significant impact factors

\begin{tabular}{lccccc}
\hline Factors & Economic & Health & Air & Water & Land \\
\hline Dkm & -0.268 & -0.148 & -0.473 & -0.547 & -0.516 \\
Economic & & 0.613 & 0.611 & 0.331 & 0.709 \\
Health & & & 0.263 & 0.047 & 0.384 \\
Air Pollution & & & & 0.740 & 0.834 \\
Water Pollution & & & & & 0.722 \\
\hline
\end{tabular}

Table 5. Consequence and Likelihood rating of impact factors

\begin{tabular}{|c|c|c|c|c|c|c|c|}
\hline \multirow{2}{*}{ Community } & \multirow{2}{*}{ Dkm } & \multicolumn{2}{|c|}{ Socio-economic } & \multicolumn{2}{|c|}{ Environmental } & \multirow{2}{*}{ Consequence $(\mathrm{C})$} & \multirow{2}{*}{ Likelihood (L) } \\
\hline & & Severity & Rating & Severity & Rating & & \\
\hline $\mathrm{A}$ & 7.5 & 63.8 & 2 & 63.7 & 2 & 2 & 3 \\
\hline $\mathrm{B}$ & 6.6 & 27.1 & 4 & 86.9 & 1 & 2.5 & 2 \\
\hline $\mathrm{C}$ & 6.2 & 48.8 & 3 & 31.8 & 4 & 3.5 & 2 \\
\hline $\mathrm{D}$ & 1.5 & 96.5 & 1 & 89.3 & 1 & 1 & 1 \\
\hline $\mathrm{E}$ & 3.1 & 6.9 & 5 & 48.2 & 3 & 4 & 2 \\
\hline $\mathrm{F}$ & 6.1 & 34.0 & 2 & 46.0 & 3 & 2.5 & 2 \\
\hline G & 10.3 & 48.2 & 3 & 44.4 & 3 & 3 & 4 \\
\hline $\mathrm{H}$ & 8.7 & 46.8 & 3 & 52.9 & 3 & 3 & 3 \\
\hline I & 2.0 & 96.1 & 1 & 83.3 & 1 & 1 & 1 \\
\hline $\mathrm{J}$ & 11.1 & 53.1 & 3 & 0.0 & 5 & 4 & 4 \\
\hline $\mathrm{K}$ & 8.2 & 44.0 & 3 & 38.9 & 4 & 3.5 & 3 \\
\hline $\mathrm{L}$ & 3.6 & 89.0 & 1 & 68.8 & 2 & 1.5 & 2 \\
\hline M & 8.0 & 30.3 & 2 & 45.7 & 3 & 2.5 & 3 \\
\hline $\mathrm{N}$ & 8.5 & 11.0 & 5 & 15.7 & 5 & 5 & 3 \\
\hline $\mathrm{O}$ & 4.8 & 8.7 & 5 & 25.4 & 2 & 3.5 & 2 \\
\hline $\mathrm{P}$ & 13.5 & 60.8 & 2 & 29.0 & 2 & 2 & 4 \\
\hline Q & 14.7 & 56.8 & 3 & 22.0 & 2 & 2.5 & 5 \\
\hline $\mathrm{R}$ & 11.3 & 57.2 & 3 & 54.5 & 3 & 3 & 4 \\
\hline $\mathrm{S}$ & 16.1 & 21.9 & 4 & 42.8 & 3 & 3.5 & 5 \\
\hline $\mathrm{T}$ & 6.8 & 66.0 & 2 & 56.8 & 3 & 2.5 & 2 \\
\hline
\end{tabular}

3.2 Apportionment Data Manipulation Using Ranked Risk Assessment Values

In table 5, the Risk Value $(\mathrm{RV})$ was calculated as $\left(\mathrm{C}^{*} \mathrm{~L}\right)$, ranked in an increasing order of magnitude, designated as risk rank (RR) and used to calculate remediation Factor (RF) and Apportionment (AP) \% values from equations 1 and 2, respectively. Where multiple sites have the same AP\% value the site with the lower D km was given the advantage as presented in Table 6 .

Table 6. Remediation and Apportionment (AP) \% values

\begin{tabular}{cccccc}
\hline Community & $\mathrm{Dkm}$ & $\mathrm{RR}$ & $\mathrm{RF}_{\mathrm{i}}$ (Eq. 1) & $\mathrm{AP}_{\mathrm{RR}} \%$ (Eq. 2) & Order of Priority (OP) \\
\hline $\mathrm{D}$ & 1.5 & 1 & 24.0 & 7.23 & 1 \\
$\mathrm{I}$ & 2 & 1 & 24.0 & 7.23 & 2 \\
$\mathrm{~L}$ & 3.6 & 3 & 22.0 & 6.63 & 3 \\
$\mathrm{~F}$ & 6.1 & 5 & 20.0 & 6.02 & 4 \\
$\mathrm{~B}$ & 6.6 & 5 & 20.0 & 6.02 & 5 \\
$\mathrm{~T}$ & 6.8 & 5 & 20.0 & 6.02 & 6 \\
$\mathrm{~A}$ & 7.5 & 6 & 19.0 & 5.72 & 7 \\
$\mathrm{O}$ & 4.8 & 7 & 18.0 & 5.42 & 8 \\
$\mathrm{C}$ & 6.2 & 7 & 18.0 & 5.42 & 9 \\
$\mathrm{M}$ & 8.0 & 7.5 & 17.5 & 5.27 & 10 \\
$\mathrm{E}$ & 3.1 & 8 & 17.0 & 5.12 & 11 \\
$\mathrm{P}$ & 13.5 & 8 & 17.0 & 5.12 & 12 \\
$\mathrm{H}$ & 8.7 & 9 & 16.0 & 4.82 & 13 \\
$\mathrm{~K}$ & 8.2 & 10.5 & 14.5 & 4.37 & 15 \\
$\mathrm{G}$ & 10.3 & 12 & 13.0 & 3.92 & 16 \\
$\mathrm{R}$ & 11.3 & 12 & 13.0 & 3.92 & 17 \\
$\mathrm{Q}$ & 14.7 & 12.5 & 12.5 & 3.77 & 19 \\
$\mathrm{~N}$ & 8.5 & 15 & 10.0 & 3.01 & 20 \\
$\mathrm{~J}$ & 11.1 & 16 & 9.0 & 2.71 & \\
$\mathrm{~S}$ & 16.1 & 17.5 & 7.5 & 2.26 &
\end{tabular}


In table 6 , communities D and I, located at $1.5 \mathrm{~km}$ and $2.0 \mathrm{~km}$, respectively from the mining focus have the highest apportionment of $7.23 \%$, while, community S located at $16.1 \mathrm{~km}$ has the lowest apportionment of $2.26 \%$. The above may be used as a standard for any other simulations.

\subsection{Apportionment Model Simulations Using Distance Variations}

It is very important that sets of related data are effectively validated for future applications and simulation of dependent variables such as the $\mathrm{AP}_{\mathrm{RR}} \%$ in relation to changes in the $\mathrm{RR}$ and $\mathrm{D} \mathrm{km}$ as independent variables in this research. The data presented in Table 6 were therefore compared using a t-test performed at $95 \%$ confidence limit (CL). The condition for the t-test was based on the null hypothesis that the mean difference of $\mathrm{AP}_{\mathrm{RR}} \%$ and $\mathrm{D} \mathrm{km}$ and the mean difference of $\mathrm{AP}_{\mathrm{RR}} \%$ and $\mathrm{RR}$ are equal against the alternatives that the mean differences of the paired variables are not equal. Results from the t-tests are presented in Table 7.

Table 7. Paired T for the paired variables of AP\%- RR and AP\%-D

\begin{tabular}{|c|c|c|c|c|c|c|c|}
\hline Parameter & Mean & St. Dev & SE Mean & Parameter & Mean & St. Dev & SE Mean \\
\hline$R R$ & 10.50 & 5.916 & 1.323 & $D \mathrm{~km}$ & 7.93 & 4.037 & 0.903 \\
\hline$A P_{R R} \%$ & 5.00 & 1.408 & 0.315 & $A P_{R R} \%$ & 5.00 & 1.408 & 0.315 \\
\hline Difference & 5.50 & 7.302 & 1.633 & Difference & 2.93 & 5.236 & 1.171 \\
\hline \multicolumn{4}{|c|}{$95 \%$ CI for mean difference $(2.083,8.917)$} & \multicolumn{4}{|c|}{$95 \%$ CI for mean difference $(0.479,5.381)$} \\
\hline \multicolumn{4}{|c|}{ T-Test of mean difference $=0(v$ s not $=0)$ : } & \multicolumn{4}{|c|}{ T-Test of mean difference $=0(v$ s not $=0)$ : } \\
\hline \multicolumn{4}{|c|}{$T$-Value $=3.37$ P-Value $=0.003$} & \multicolumn{4}{|c|}{$T$-Value $=2.50$ P-Value $=0.022$} \\
\hline
\end{tabular}

In table 7, the test statistic values of $\mathrm{RR}$ and $\mathrm{D} \mathrm{km}$ against the means of $\mathrm{AP}_{\mathrm{RF}} \%$ are 0.003 and 0.022 , while the table values are 3.37 and 2.50 , respectively. The table values are higher than the significance values, hence the null hypothesis that the means of the paired variables are equal is not rejected. The paired variables were used to generate regression models as presented in Figures 2.
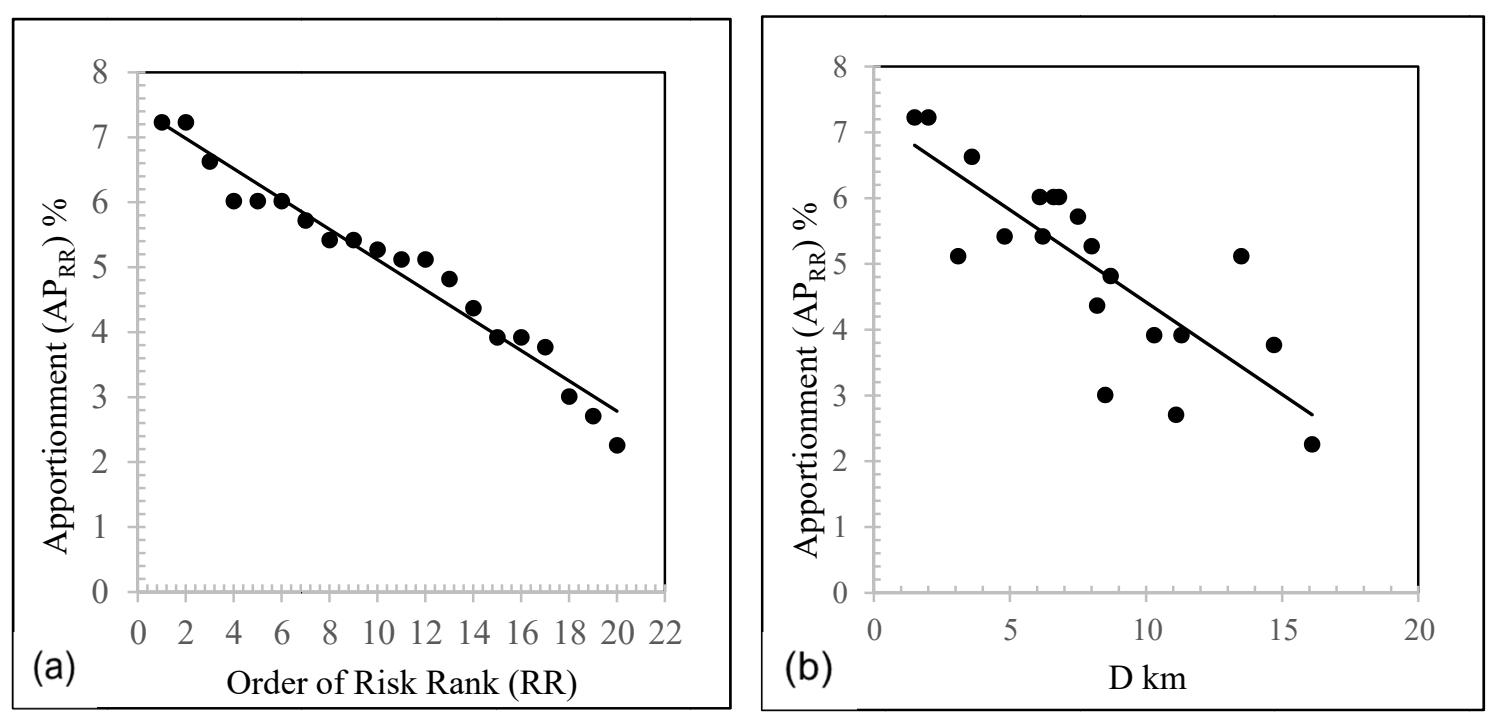

Figure 2 Apportionments $\left(\mathrm{AP}_{\mathrm{RR}}\right) \%$ expressed in terms of (a) $\mathrm{OP}$ and (b) $\mathrm{D} \mathrm{km}$

From Figure 2(a), the equation and $\mathrm{R}^{2}$ for $\mathrm{AP}_{\mathrm{RF}} \%$ based on risk assessment is defined by:

$$
\mathrm{AP}_{\mathrm{RR}} \%=7.4499-0.2333(\mathrm{RR}) \ldots \ldots . . \mathrm{R}^{2}=0.961
$$

From equation 3, the $\mathrm{R}^{2}$ value $\left(\mathrm{R}_{\mathrm{RR}}^{2}=0.961\right)$ indicates that $96.1 \%$ of the variation in $\mathrm{AP}_{\mathrm{RR}} \%$ is determined by the relationship between $A P_{R R} \%$ and $R R$. The residual $R^{2}$ value $\left(R_{R R}^{2}=0.039\right)$ indicates that $3.9 \%$ of the variation is unexplained; this value is less than the $5 \% \mathrm{CL}$, hence the model is valid and attainable from a long-term procedure. A short-term model can, therefore, be developed for interim use, based on the $\mathrm{AP}_{\mathrm{RR}} \%$ model parameters derived from Figure 2(b) as:

$$
\mathrm{AP}_{\mathrm{RR}} \%=7.2248-0.2806(\mathrm{D}) \ldots \ldots . .\left(\mathrm{R}^{2}=0.647\right) .
$$


From equation 4 , the $R^{2}$ value $\left(R_{D}^{2}=0.647\right)$ indicates that $64.7 \%$ variation in $A_{R R} \%$ is determined by the relationship between $A P_{R R} \%$ and $D \mathrm{~km}$. The residual $\mathrm{R}^{2}$ value $\left(\mathrm{R}_{\mathrm{D}}^{2}{ }^{1}=0.353\right)$ indicates that $35.3 \%$ of the variation is unexplained; this value is greater than $5 \% \mathrm{CL}$, hence the model is invalid.

For a valid distance-based model, the estimated distances were substituted in equation (4) and the results $\left(A P_{D}\right)_{i}$ multiplied by a constant ' $K$ ' such that $\left[\mathrm{AP}_{\mathrm{RR}}-\left(\mathrm{K}^{*} A \mathrm{P}_{\mathrm{D}}\right)\right]_{\mathrm{i}} \geq 0$, to avoid negative values. In this research, $\mathrm{K}$ is defined as: $\left.\left[\mathrm{R}_{\mathrm{D}^{-}}{ }^{-}\left(\mathrm{R}_{\mathrm{D}^{*}}^{2} \mathrm{R}_{\mathrm{RR}}^{2}\right)\right]=\mathrm{R}_{\mathrm{D}}^{2}\left(1-\mathrm{R}_{\mathrm{RR}}^{2}\right)\right]=0.647 *(1-0.039)=0.622$, where $\left(\mathrm{R}_{\mathrm{D}^{2}}^{2} \mathrm{R}_{\mathrm{RR}}^{2}{ }^{1}\right)$ is the component of the unexplained variation due to $\mathrm{R}_{\mathrm{D}}^{2}$ in $\mathrm{R}_{\mathrm{RR}}^{2}{ }^{1}(0.039)$. All the computations from the simulations outlined above are presented in Table 8.

Table 8

\begin{tabular}{cccccc}
\hline Communities(order of $\mathrm{RR})$ & $\mathrm{AP}_{\mathrm{RR}}$ & $\mathrm{AP}_{\mathrm{D}}$ & $\left(\mathrm{AP}_{\mathrm{RR}}-\mathrm{AP}_{\mathrm{D}}\right)$ & $\left(\mathrm{K}^{*} \mathrm{AP} \mathrm{D}\right)$ & {$\left[\mathrm{AP}_{\mathrm{RR}}-\left(\mathrm{K}^{*} \mathrm{AP} \mathrm{P}_{\mathrm{D}}\right)\right]$} \\
\hline $\mathrm{D}(1)$ & 7.23 & 6.80 & 0.43 & 4.23 & 3.00 \\
$\mathrm{I}(2)$ & 7.23 & 6.66 & 0.57 & 4.14 & 3.09 \\
$\mathrm{~L}(3)$ & 6.63 & 6.21 & 0.42 & 3.87 & 2.76 \\
$\mathrm{~F}(4)$ & 6.02 & 5.51 & 0.51 & 3.43 & 2.59 \\
$\mathrm{~B}(5)$ & 6.02 & 5.37 & 0.65 & 3.34 & 2.68 \\
$\mathrm{~T}(6)$ & 6.02 & 5.32 & 0.70 & 3.31 & 2.71 \\
$\mathrm{~A}(7)$ & 5.72 & 5.12 & 0.60 & 3.18 & 2.54 \\
$\mathrm{O}(8)$ & 5.42 & 5.88 & -0.46 & 3.66 & 1.76 \\
$\mathrm{C}(9)$ & 5.42 & 5.49 & -0.07 & 3.41 & 2.01 \\
$\mathrm{M}(10)$ & 5.27 & 4.98 & 0.29 & 3.10 & 2.17 \\
$\mathrm{E}(11)$ & 5.12 & 6.35 & -1.23 & 3.95 & 1.17 \\
$\mathrm{P}(12)$ & 5.12 & 3.44 & 1.68 & 2.14 & 2.98 \\
$\mathrm{H}(13)$ & 4.82 & 4.78 & 0.04 & 2.97 & 1.84 \\
$\mathrm{~K}(14)$ & 4.37 & 4.92 & -0.55 & 3.06 & 1.31 \\
$\mathrm{G}(15)$ & 3.92 & 4.33 & -0.41 & 2.70 & 1.22 \\
$\mathrm{R}(16)$ & 3.92 & 4.05 & -0.13 & 2.52 & 1.40 \\
$\mathrm{Q}(17)$ & 3.77 & 3.10 & 0.67 & 1.93 & 1.84 \\
$\mathrm{~N}(18)$ & 3.01 & 4.84 & -1.83 & 3.01 & 0.00 \\
$\mathrm{~J}(19)$ & 2.71 & 4.11 & -1.40 & 2.56 & 0.15 \\
$\mathrm{~S}(20)$ & 2.26 & 2.71 & -0.45 & 1.68 & 0.58 \\
\hline
\end{tabular}

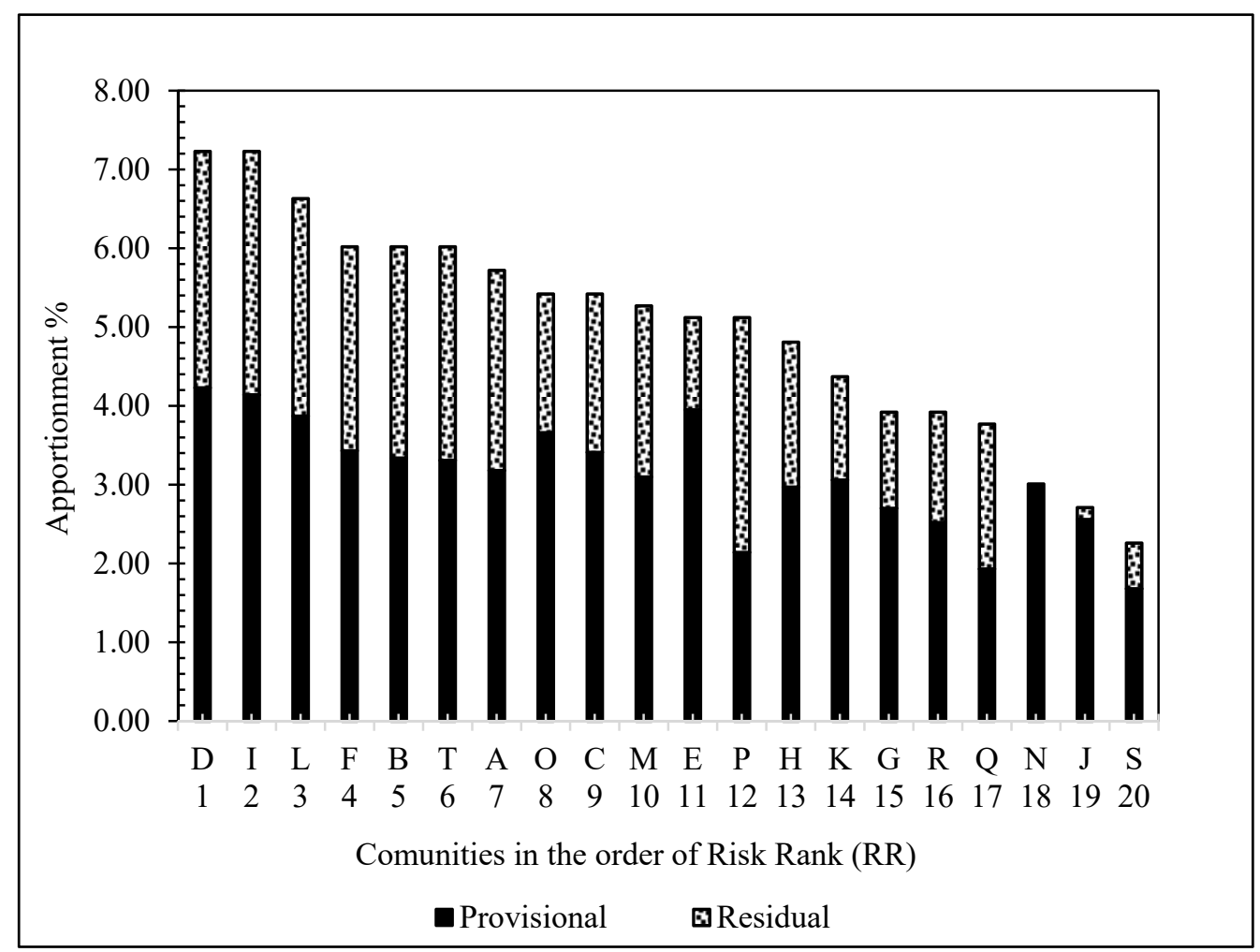

Figure 4 Composite Apportionment Chart 
In table 8, the residual estimates $\left(\mathrm{AP}_{\mathrm{RR}}-\mathrm{AP}_{\mathrm{D}}\right)$, which is computed without the constant ' $\mathrm{K}$ ' contain negative values which are anomalous. This anomaly is due to the high unexplained $R^{2}$ component $\left(R^{2}{ }^{1}\right.$ value of 0.353$)$ in the distance model, which is far above the alpha value of $0.05 \mathrm{CL}$. After multiplying the $\mathrm{AP}_{\mathrm{R}}$ with the constant $\mathrm{K}$, the residual $\left[\mathrm{AP}_{\mathrm{RR}}-\left(\mathrm{K}^{*} \mathrm{AP} \mathrm{P}_{\mathrm{D}}\right)\right]$ become non-negative and used appropriately. The apportionments are presented in Figure 4.

From Figure 4, it is evident that the distance model can be used as an input data at the pre-project stage. The advantage is that communities would remain at ease in anticipation of a residual payment at the closure stage, where there would be enough data for a risk assessment to compare with the provisional model. For a community that breaks even for a residual such as $\mathrm{N}$, some arbitrary award from the environmental reclamation bond may be used as a token.

\section{Conclusions and Recommendations}

Significant impact factors in this research are; cost of living and health factors, air and water pollutions, land degradation and distance variations, while alcoholism, stealing, narcotic use, prostitution and medicinal plant use are not significant. A long-term apportionment (AP) criterion using risk rank (RR) of communities is defined by $\mathrm{AP}_{\mathrm{RR}} \%=7.45-0.233(\mathrm{RR})$. The $\mathrm{AP}_{\mathrm{RR}} \%$ model equation in terms of distance is defined by $\mathrm{AP}_{\mathrm{RR}} \%=7.22-0.281(\mathrm{D})$, leading to a short-term provisional apportionment criterion defined by $\mathrm{K}^{*} A \mathrm{P}_{\mathrm{D}}=4.13-0.097(\mathrm{RR})$, where $\mathrm{K}=\mathrm{R}_{\mathrm{D}}^{2}$ $\left(1-\mathrm{R}_{\mathrm{RR}}^{2}\right)$. The expression; $\left(\mathrm{AP}_{\mathrm{RR}}-\mathrm{K}^{*} \mathrm{AP} \mathrm{P}_{\mathrm{D}}\right)$ is the residual apportionment value required in the long-term to complement the short-term provisional apportionment. The findings in this research show clearly defined trends that can be replicated for similar future projects. It is recommended that the methods of this apportionment compensation criteria be extended to areas beyond Forest Reserve environments as well. This will help achieve the global goals of environmental excellence in all facets of society, where mining projects are undertaken.

\section{References}

Akabzaa, T. M. (2000). Boom and Dislocation: A Study of the Social and Environmental Impacts of Mining in the Wassa West District of Ghana. Third World Network, Africa Secretariat: Accra, Ghana.

Akabzaa, T. M., Banoeng-Yakubo, B. K., \& Seyire, J. S. (2007). Impact of mining activities on water resources in the vicinity of the Obuasi mine. West African Journal of Applied Ecology, 11(1), 101-109.

Akabzaa, T., \& Darimani, A. (2001). Impact of mining sector investment in Ghana: A study of the Tarkwa mining region. Third World Network. Retrieved from http://www.saprin.org/

Anderson, B. A., Romani, J. H., Phillips, H., Wentzel, M., \& Tlabela, K. (2007). Exploring environmental perceptions, behaviors and awareness: water and water pollution in South Africa. Population and Environment, 28(3), 133-161.https://doi.org/ 10.1007/s11111-007-0038-5

Aryee, B. N. (2001). Ghana's mining sector: its contribution to the national economy. Resources Policy, 27(2), 61-75.

Asante-Duah, D. K. (1996). Managing Contaminated Sites; Problems Diagnosis and Development of Site Restoration. London: John Wiley and Sons.

Awudi, G. B. (2002, February). The role of foreign direct investment (FDI) in the mining sector of Ghana and the environment. In Conference on Foreign Direct Investment and the Environment, OECD, Paris.

Ayitey, J. Z., Kidido, J. K., \& Tudzi, E. P. (2011). Compensation for land use deprivation in mining communities, the law and practice: case study of Newmont Gold Ghana Limited. Retrieved from https://scholar.google.com/citations?user....

Banks, G. (2009). Activities of TNCs in extractive industries in Asia and the Pacific: implications for development. Transnational Corporations, 18(1), 43.

Birkmann, J. (2007). Risk and vulnerability indicators at different scales: Applicability, usefulness and policy implications. Environmental hazards, 7(1), 20-31.

Buadee, N. A., Gawu, S. K. Y., \& Foli, G. (2018). Assessing the Occupational Risks associated with Artisanal and Small-Scale mining-A Case study in Asankrangwa and Kenyasi Areas in Ghana. West African Journal of Applied Ecology, 26(1), 22-32.

Dietz, T., Fitzgerald, A., \& Shwom, R. (2005). Environmental values. Annu. Rev. Environ. Resour., 30, 335-372. https://doi.org/10.1146/annurev.energy. 30.050504.144444.

Filer, C. (1990). The Bougainville rebellion, the mining industry and the process of social disintegration in Papua New Guinea. Canberra Anthropology, 13(1), 1-39. 
Filer, C., Henton, D., \& Jackson, R. (2000). Landowner Compensation in Papua New Guinea's Mining and Petroleum Sectors. PNG Chamber of Mines and Petroleum.

Foli, G., Hogarh, J. N., \& Antwi-Agyei, P. (2010). Effectiveness of planning and implementation stages of the ISO 14001 standards EMS at the Obuasi gold mine, Ghana. Am. J. Soc. Mgmt. Sci, 1(1), 1-12. https://doi.org/10.5251/ajsms. 2010.1.1.1.12

Foli, G., Nude, P. M., Amedjoe, C. G., \& Kyei, L. (2012). Arsenic Leaching in Mill Tailings at the AngloGold Ashanti-Obuasi Mine, Ghana: management of contamination in the related water environment. West African Journal of Applied Ecology, 20(1), 11-23.

GBN. (2016) Ghana Business News. Retrieved July 4, 2018, from https:/www.ghanabusinessnews.com/2016/10/19/mining-Contributes-some-4b-to-ghanas-economy-in-201 5/:

GMET. (2016). Ghana Meteorological Agency. Retrieved February 14, 2018, from www.meteo.gov.gh

Harris, P. G. (2006). Environmental perspectives and behavior in China: Synopsis and bibliography. Environment and behavior, $38(1), 5-21$.

Hinkle, D. E., Wiersma, W., \& Jurs, S. G. (2003). Applied Statistics for the Behavioural Sciences (5th Ed.).

Hunter, L. M. (2006). Household strategies in the face of resource scarcity in coastal Ghana: are they associated with development priorities?. Population research and policy review, 25(2), 157-174. https://doi.org/10.1007/s11113-006-9002-9.

InfoMine, (2013). Mine sites, Major mining operations around the world: Chirano Mines. Retrieved from $\mathrm{http} / /$ www.infomine.com/mine site/...Chirano

Kanani, S., \& Zandi, H. (2011). A study of the damages to historical monuments due to climatic factors and air pollution and offering solutions. WASET, 56, 593-596.

Kidido, J. K., Ayitey, J. Z., Kuusaana, E. D., \& Gavu, E. K. (2015). Who is the rightful recipient of mining compensation for land use deprivation in Ghana?. Resources Policy, 43, 19-27. http://dx.doi.org/10.1016/j.resourpol.2014.10.0040301-4207/\&2014

Leube, A., Hirdes, W., Mauer, R., \& Kesse, G. O. (1990). The early Proterozoic Birimian Supergroup of Ghana and some aspects of its associated gold mineralization. Precambrian Research, 46(1-2), 139-165.

Modern Ghana. (2018). Ghana's Population. Retrieved from https:www.modernghana.com>news

Nude, P. M., Foli, G., Gawu, S. K. Y., Gidigasu, S. S. R., Sakyi, P. A., \& Kwayisi, D. (2016). Arsenic Intensity Risk Assessment at AngloGold Obuasi Goldmine, Ghana, West Africa: Using Sorption and Geotechnical Factors. West African Journal of Applied Ecology, 24(2), 1-17.

O'Faircheallaigh, C. (1992). The local politics of resource development in the South Pacific: Towards a general framework of analysis. Resources, Development and Politics in the Pacific Islands, 258-289.

Sarkodie, P. H., Nyamah, D., \& Amonoo-Niezer, E. H. (1997, June). Speciation of arsenic in some biological samples from Obuasi and its surrounding villages. In Pp. $146 \ddot{y} 154 \mathrm{in}$ : National symposium proceedings $\ddot{y}$ the mining industry and the environment, April 14̈̈15, Kumasi, UST.

Saunders, M., Lewis, P., \& Thornhill, A. (1997). Research methods for business students, Pitman.

White, M.J. \& Hunter L.M. (2005). Public Perception of Environmental Issues in a Developing Setting. Institute for Behavioral Sciences: Working Paper EB2005-0003

Xiao, C., \& McCright, A. M. (2007). Environmental concern and sociodemographic variables: A study of statistical models. The Journal of Environmental Education, 38(2), 3-14.

Yao, Y., \& Robb, L. J. (2000). Gold mineralization in Palaeoproterozoic granitoids at Obuasi, Ashanti region, Ghana: Ore geology, geochemistry and fluid characteristics. South African Journal of Geology, 103(3-4), 255-278.https://doi.org/10.2113/1030255

\section{Copyrights}

Copyright for this article is retained by the author(s), with first publication rights granted to the journal.

This is an open-access article distributed under the terms and conditions of the Creative Commons Attribution license (http://creativecommons.org/licenses/by/4.0/). 